\title{
Study on the Influence of Customers' Risk Perception on the Use of Leasing Services Based on the Burden of Ownership
}

\author{
Jutamart Limsupanark ${ }^{1}$, Xu Ming ${ }^{1}$, Pimyada Pangam ${ }^{2}$ \\ ${ }^{1}$ Glorious Sun School of Business and Management, Donghua University, Shanghai, China \\ ${ }^{2}$ International College of Social Science and Communication, Dhurakij Bundit University, Bangkok, Thailand \\ Correspondence: Jutamart Limsupanark, Glorious Sun School of Business and Management, Donghua \\ University, No. 1882, Yan'an West Road, Changning District, Shanghai 200051, China. \\ E-mail: ju_meichai@yahoo.com
}

Received: November 17, 2016

Accepted: November 13, 2017

Online Published: January 20, 2017

doi:10.5539/ibr.v10n2p147

URL: http://dx.doi.org/10.5539/ibr.v10n2p147

\begin{abstract}
Rental service refers to the provision of the right to use the goods for the customer, and do not need to have ownership, such as the car rental industry, is now growing rapidly. This service is provided to avoid the so-called "customers to bear the burdens of ownership", such as the product has to take the risk and responsibility. However, the use of issues such as risk perception and subsequent customer facing to obtain the ownership of the products of leasing services need further study. Based on the theory of risk perception, we propose five risk dimensions (economic risk, performance risk, psychological risk, time risk and social risk). They have an impact on customer's decision in rental service. Through the analysis of the data obtained by the investigation, we examined the hypothesis. The results proved that the decision of customer to obtain the ownership is affected by the five kinds of risk perception factors; while the ownership intention declines, the intention to use rental service will increase.
\end{abstract}

Keywords: rental service consumption, sharing, risk perception, ownership

\section{Introduction}

Berry and Maricle (1973) considered the ownership of articles would cause "Burden of Ownership", which includes the risk of product changes and elimination, the wrong decisions on product choosing, the obligation of product maintenance and repair, and the risk of bad performance and low performance-price ration. These kinds of burdens may cause the unwillingness of customers to possess the ownership of the products. For some products, the form of "Non-ownership" to obtain the right to use the product, it is a kind of alternative form of consumption.

Tobias Schaefers (2015) proposed the concept of "Access-based Service”, which referred to a kind of business activity of providing customers the right to use a product during a specific time period. It differs from the ownership obtained from purchasing the product, which is obtaining more attention from scholars. (Bardhi and Eckhardt 2012; Belk 2013; Moeller and Wittkowski 2010; Wirtz and Ehret 2009). Leasing is the commercial form of "Access-based service", which is a business model of renting products instead of owning products, include automobile renting or bike renting (e.g: CAR Inc., Zipcar, Capital Bikeshare), short-term renting of fashion products (e.g: Bag Borrow or Steal), P2P platform (e.g: mayi.com, RelayRides, Airbnb). Lovelock and Gummesson (2004) propose "this kind of non-ownership exchange is different from other forms", it eliminates customers' ownership of the products and any risks associated with the ownership (Moeller and Wittkowski, 2010). It is not a new business model (Babione, 1964). With the popularity of the Internet, Sharing Economy grows rapidly, ICT distributes and integrates idle and underutilized resources effectively, lessors and the lessees could make deals more quickly (Belk, 2013). During the past 15 years, The spending in leasing and rental increased by 55\% from 90 billion in 1998 to 139 billion in 2013 (US Census Bureau, 2014). Various types of risk capitals are in favor of such enterprises for example Airbnb (family hotel services) valued at $\$ 20$ billion or Uber (short rental cars) valued at $\$ 41$ billion. A "sharing revolution" has begun in conjunction with the social media and the popularity of mobile Internet (Bruce 2012). 
Existing literature focuses on research on perceived risk and its influence (e.g: Barone et al. 1999; Kamleitner and Erki 2013). Lovelock and Gummesson (2004) believe that further study could be achieved through different perspectives. Although existing literature already explored ownership issues from the perspective of customer behavior (e.g: Bardhi and Eckhardt, 2012; Durgee and O'Connor, 1995; Moeller and Wittkowski, 2010), some questions still need better answers, especially for the study on substitutes of ownership consumption patterns under so-call "Burdens of ownership" model (Moeller and Wittkowski, 2010). Obtaining ownership often means risks and liabilities, which is the main reason why customers are willing to use the products instead of willing to obtain the ownership of the products. If the customers perceive the risks of owning products, they will increase their choices of using leasing services and neglect ownership of the products (Wittkowski et al., 2013). The risk of product retirement is the main factor enterprises choose rental service. But from the perspective of multiple risk dimensions, there is lack of research on theoretical and empirical study based on influence of burdens of ownership to service choosing and behavior related to ownership decisions. This study focuses on customers' willingness to use product rental services influenced by the willingness of obtaining the ownership based on customers' different dimensions of risk perception which caused by burden of ownership. According to the Risk Perception Theory (Bauer 1960; Mitchell 1999), we developed relevant theoretical models and used first-hand research data for validation. Contribution to existing research including: the empirical study researched on the relationship among burdens of ownership; willingness to obtain ownership and subsequent willingness of using rental services. In particular, we proposed a hypothesis of customers' selection on services influenced by the perceptions of economic risk, performance risk, psychological risk, time risk and social risk of the products. The higher the perceived risk level is, the less willingness of owning the products the customers have.

\section{Burden of Ownership and Perceptions of Risk}

According to Property Theory, a series of property rights can be classified and restructured according to the properties of the resources (Alchian and Demsetz, 1973; Coase, 1960). Four types of property rights can be classified (Furubotn and Pejovich, 1972) as the right to use articles; the right gained from the outputs by using articles; the right to change the structure and properties of the articles; the right to transfer the property to one or more other persons. Schwab (2007) considered ownership of the article gives owner the rights of use, control, manage and enjoy the article-include the right to transfer it to others. Ownership authorized this person's absolute control of the article (including the accompany right of the article) under existing legal framework. In general, owning an article means owning four rights mentioned above. Individuals using four rights could use the article exclusively, non-restriction under current legal framework (Demsetz, 1967).

As a mode of consumption, customers obtain ownership by purchasing products and then get the right to use the products. Compare to acquired ownership, rental service allows customers to have the right to use the product in a specific time period (Durgee and O'Connor, 1995). Based on previous research (Bardhi and Eckhardt, 2012; Lovelock and Gummesson, 2004), scholars define rental service as: a market exchange behavior which customers obtain the temporary and limited right to use a product by paying a certain amount of fee, but the service provider still has the legal ownership of the product. The core of rental service is the assets can be used continuously for more than one individual (i.e, sharing) over a period of time. The feature of rental service which meets the needs of multiple individuals' temporary use differs from services which meet single individual's (i.e, the product owner) unlimited use of an asset.

The main differences between purchasing and rental service are "Burden of Ownership" (Moeller and Wittkowski, 2010) and risks and responsibilities related. Customer Risk Perception refers to any result from the customer behavior caused by unpredictable consequences - often negative consequences, which is a concept proposed by Bauer and others in marketing area in 1960's (Bauer, 1960 and Cox, 1967, in Rindfleisch and Crockett, 1999). Sweeney and others (1999) pointed out that risk perception is a subjective predictable of the extent of the losses. In other words, customers' subjective risk perceptions include the results caused by wrong decisions and products failed to meet the expected level (Roselius, 1971). Jacoby and Kaplan (1972) made some improvements based on Bauer's research: risk perception is a multi-dimensional concept includes economic, performance, physical, psychological and social risks. Other scholars consider all the ownership risks customers facing are economic risk, performance risk, social risk (DelVecchio and Smith 2005), depreciation risk and inefficient use risk (Berry and Maricle, 1973). The risks also include certain assets' maintaining and repairing responsibilities. On the other hand, if customers choose rental service, the only choice they have to make decision on is service selection. Compare to owning ownership, rental service leads to customers' cost-effectiveness (Wirtz and Ehret 2009). Mumel (1999) added time risk, which refers to time costs to search a product if costumer's expectation on the product's performance is not satisfied. This kind of multi-dimensional perspective accepted by other researchers soon (e.g Peter and Ryan, 1976; Bearden and Mason, 1978; Brooker, 
1983; Peter and Tarpey, 1975, in Rindfleisch and Crockett, 1999). Researchers use risk perception in other fields e.g Slovic et al., 1984; Rindfleisch and Crockett, 1999).

Risk perception theory focuses on customers' subjective risk perception level (Dowling and Staelin 1994). In general, risk can be divided into two categories; dominant and recessive risk (DelVecchio and Smith 2005). Dominant risk could cause potential negative influence to the results of purchasing decision. Recessive risk includes (not) definite results. With the increase of different kinds of risk, more negative (less positive) results appear- risk level related to purchasing decision. Although different individuals have different risk preferences (Cho and Lee 2006), customers always avoid risks. Previous research also indicated that with the increase of risk perception, negative influence on the product's evaluation will increase (Ofir and Bechtel 1990), possibility of acceptance decreases (Forsythe and Shi 2003), and payment willingness decreases (Maier et al. 2014). If a high-leveled risk perception exists though a purchasing process, decision makers may change or give up purchasing idea.

\subsection{Hypothesis Factor Influence Customers' Purchasing Decision}

However, Customers' purchasing decision may focus on different angles as economic risk, performance risk, psychological risk, time risk and social risk (DelVecchio and Smith, 2005).

1) Economic Risk

Economics risk refers to the uncertain potential economic loss related to purchasing decision. In general, economic risk raises product's price. Compare with ownership, use-based service only requires customers to pay a certain percentage of fee (e.g count by time). This kind of fee is much lower than fee of purchasing the product (Lovelock and Gummesson, 2004). Although the long-term rental fee is higher than purchasing fee one-time rental fee is lower and more predictable (Durgee and O'Connor 1995). Besides, no opportunity cost is added into rental service compared to purchasing. If customers predict higher economic risk of ownership, their willingness of owning the ownership will decrease (H1).

\section{2) Performance Risk}

Performance Risk refers to the uncertainty of whether the customers' expectation/exception on product's performance is satisfied (Bauer 1960). It includes the risk from uncommon usage of the product caused by the quality problem and the risk of maintenance and replacement. Because of the responsibilities of owner on the product's maintenance and replacement; high performance risk causes after-purchasing additional cost and the physical and mental cost that caused by low performance. In summary, the higher performance risk on purchasing of any product it possesses, the lower willingness of owning the customers will have (H2).

\section{3) Psychological Risk}

Psychological risk refers to customers' negative psychological influence caused by choosing wrong products (Murphy and Enis, 1986). High psychological risk means customers' doubt on self-skills and possibility of their higher skills with a wrong decision on purchasing (Stone and Gronhaug, 1993). Purchasing decision on high-valued products also related to higher deciding responsibility, this will cause doubt and gainsay on customers' self-imagine and capacity after purchasing. As a result, if customers have higher psychological risk perception, the willingness to own the ownership will decrease (H3).

\section{4) Time Risk}

Time risk refers to time costs spend to find a product, if the customers' expectation on a product's performance is not satisfied (Mumel, 1999). Purchasing a product, especially purchasing high-valued products needs searching, comparing, receiving, or even returning, which all needs a lot of time. Although with the popularity of the Internet, searching, comparing and paying become more convenience, more purchasing performance will be done on the Internet, customers still need to spend a lot of time purchase high-valued products and products hard to transport off-line. Thus, higher time risk perception customers have, lower willingness on ownership (H4).

\section{5) Social Risk}

Social risk means the extend of others' evaluation and customers' social status influenced by purchasing. In general, an individual's information is transferred to others with purchasing and owning the product (Belk, 1988). High social risk means others' uncertain evaluation on buyers' purchasing decisions. Owning a product often means long-term commitment to the product and also a clear message to others on the commitment. On the other hand, rental service needs no commitment; just own temporary and limited affiliation. Compare with the ownership, rental service has lower social risk. Besides, previous research also shows social influence on individual's willingness to participate. Other research also shows customers choose rental service often have 
higher social identity (Trocchia and Beatty 2003). In summary, higher social risk means lower willingness of ownership (H5).

\section{Willingness on Ownership and Rental Service}

The studies above illustrate risk perception influence on ownership, we then further consider relationship between their willingness to use rental service. In fact, rental a product offers the customers an alternative choice to own the ownership other than purchasing. On the one hand, customers can meet their needs by purchasing goods and obtain product ownership (e.g purchasing a car), or using rental service (e.g car rental service). Choosing a practical alternative service usually means it replaces the service owning a product offers. In other words, the lower willingness customers have to own the ownership, the higher their willingness to use alternative service they have, rental service enables customers to meet the needs and offers ways to reduce the burden of ownership. Other studies find out that in general, when compare with non-customers, car-sharing customers are more willing to reduce their ownership during their usage of rental service (Martin et al., 2010), thus we consider the willingness to reduce ownership contain a positive impact on the willingness to use rental services as well (H6). Hence scholars process empirical examine of the effect between ownership willingness and rental service willingness based on the hypothesis above. We constructed research as the model below.

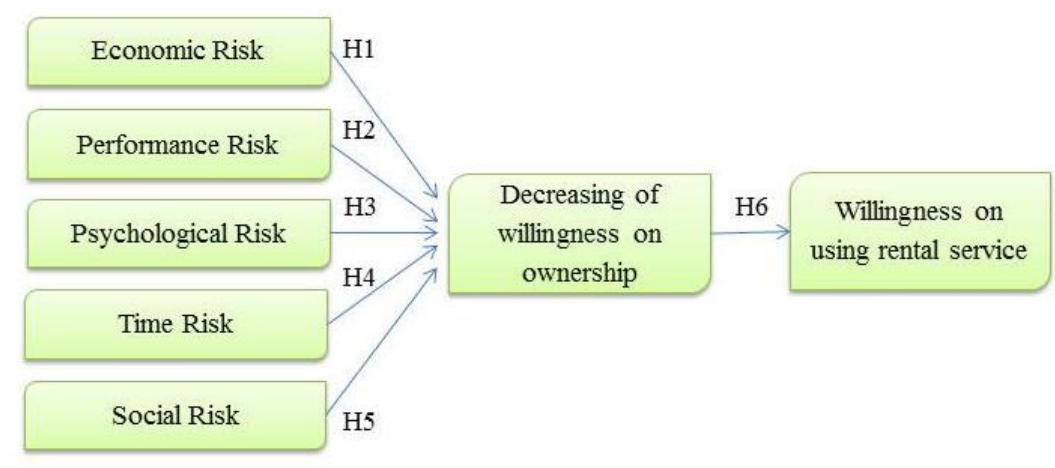

Figure 1. Research Model

\section{Model Measurement and Inspection}

\subsection{Program Design and Data Collection}

We cooperated with a Shanghai Automotive Portal company and obtained relevant data from the online registered users. Such users have relatively clear requirements of purchasing a car at first time or re-purchase. As an alternative option to car ownership, rental (sharing) cars are becoming more popular (Shaheen et al. 2009). Registered customers could get a short-term right to use the car based on timely payment. Rental Car Service (sharing) is one of the most mature rental service of the current market (Bardhi and Eckhardt 2012; Belk 2013), which is very suitable for this study. As return, customers could get a small gift related to motor vehicle after the questionnaire had completed. A total of 785 customers participated in the survey, we collected their car purchasing and car rental-related information. Invalid samples removed, we finally obtained 774 valid samples. The proportion of male in the sample is $69.7 \%$, with an average age of 33.1 .

\subsection{Questionnaire and Measurement Methods}

According to the model, we referred to customer risk perception and car rental related documents and developed a measurement scale based on practical circumstances. Meanwhile, to ensure the reliability of the questionnaire, we discussed with rental practitioners and scholars major in management and got the final scale. We use Likert 5 Point scale, reference on DelVecchio and Smith (2005)'s research on perception risk, designed 15 measurement items. Reduced ownership willingness included 2 measurement items: not willing to purchasing a car if future condition allows; I do not think purchasing a car is a good choice. 2 measurement items are designed for rental service: I prefer rental car service; I will get information about car rental.

\subsection{Result Analysis}

\subsubsection{Measurement Model Test}

Results of exploratory and confirmatory factors support the hypothesis factor structure. All reliability value are greater than 0.4 construct reliability and a coefficient value are greater than 0.7 . The average variance is greater 
than 0.5 ; multiple correlation coefficient shows all constructs have a good discriminant validity. Overall, the results show that the model has good compatibility measurement validity, discriminant validity and construct reliability (Table 1).

Table 1. Perceived risk factor analysis and reliability detection

\begin{tabular}{|c|c|c|c|c|}
\hline Risk & Cronbach's a & Construct reliability & Load factor & $\begin{array}{l}\text { Reliability } \\
\text { Index }\end{array}$ \\
\hline Economic Risk & 0.878 & 0.890 & & \\
\hline \multicolumn{3}{|c|}{ A huge economic risk to purchase a car } & 0.735 & 0.571 \\
\hline \multicolumn{3}{|c|}{ I am concerned about the cost of purchasing a car } & 0.867 & 0.684 \\
\hline \multicolumn{3}{|c|}{ Consider economic burden, I will regret purchasing a car } & 0.801 & 0.645 \\
\hline \multirow{2}{*}{\multicolumn{3}{|c|}{$\begin{array}{l}\text { Performance Risk } \quad 0.756 \\
\text { Consequences will be very serious if car malfunction happens }\end{array}$}} & & \\
\hline & & & 0.675 & 0.472 \\
\hline \multicolumn{3}{|c|}{ Consequences will be very serious if buy a wrong car } & 0.703 & 0.512 \\
\hline \multicolumn{3}{|c|}{$\begin{array}{l}\text { You shoule be very careful when purchasing a car because many problems will } \\
\text { occur when using the car }\end{array}$} & 0.820 & 0.670 \\
\hline Psychological Risk & 0.812 & 0.824 & & \\
\hline \multicolumn{3}{|c|}{ I would be pressured if buy a wrong car } & 0.723 & 0.523 \\
\hline \multicolumn{3}{|c|}{ I would be very frustrated if the car is as good as expected } & 0.810 & 0.650 \\
\hline \multicolumn{3}{|c|}{ If the car needs to be returned, the maintenance process would make me uneasy } & 0.846 & 0.734 \\
\hline Time Risk & 0.789 & 0.775 & & \\
\hline \multicolumn{3}{|c|}{ I need to take a long time to make decision in order to buy a right vehicle } & 0.864 & 0.670 \\
\hline \multicolumn{3}{|c|}{ Repair will cost me a lot of time if the car needs to be returned } & 0.871 & 0.612 \\
\hline \multicolumn{3}{|c|}{ A long time may be wasted to get to the car after purchasing } & 0.735 & 0.548 \\
\hline Social Risk & 0.805 & 0.804 & & \\
\hline \multicolumn{3}{|c|}{ Others may judge me buying behavior if I buy a car } & 0.781 & 0.540 \\
\hline \multicolumn{3}{|c|}{ Others may judge my car } & 0.748 & 0.673 \\
\hline \multicolumn{3}{|c|}{ I might need to explain my choice to others if buying a car } & 0.739 & 0.548 \\
\hline
\end{tabular}

Note. CFA Model Fitting: $\chi^{2} / \mathrm{df}=2.032, \mathrm{RMSEA}=0.032, \mathrm{CFI}=0.998, \mathrm{NFI}=0.983$

\subsubsection{Structure Model Test}

To count all behavioral variables (i.e., rental selection, reduced ownership), we use Mplus digital convergence algorithm standard deviation is generated by estimating maximum likelihood. Based on related fit indicts, structural model has a good goodness of fit. Overall, the assumed model is supported. Reduced ownership willingness is positively correlated with economic risk $(\gamma=0.197, \mathrm{t}=5.530, \mathrm{p}<0.001 ; \mathrm{H} 1)$, is positively correlated with performance risk $(\gamma=0.098, \mathrm{t}=2.245, \mathrm{p}<0.01 ; \mathrm{H} 2)$, is positively correlated with psychological risk $(\gamma=0.102$, $\mathrm{t}=2.245, \mathrm{p}<0.01 ; \mathrm{H} 2)$, is positively correlated with time risk $(\gamma=0.101, \mathrm{t}=2.56, \mathrm{p}<0.01 ; \mathrm{H} 3)$, is positively correlated with social risk $(\gamma=0.105, \mathrm{t}=2.287, \mathrm{p}<0.01 ; \mathrm{H} 4)$. Besides, reduced ownership willingness is positively correlated with rental service $(\beta=0.151, \mathrm{t}=3.30, \mathrm{p}<0.01 ; \mathrm{H} 6)$. Structural model fit indicts are: The ratio chi-square and its degrees of freedom $\mathrm{X}^{2} / \mathrm{df}=2.904$ is smaller than the reference value 3 ; Goodness of fit index $\mathrm{GFI}=$ 0.945 is greater than the reference value 0.9; adjusted goodness of fit index AGFI $=0.835$ is greater than the minimum requirement of 0.8 ; Specification Fit Index NFI $=0.934$ is greater than the reference value 0.9; Increase fit index IFI $=0.917$ is greater than the reference value 0.9; Comparative Fit Index CFI $=0.909$ is greater than the reference value 0.9 ; RMSEA $=0.067$ is less than the minimum requirement 0.08 . Statistical results show that the proposed model and the data fit well, the indicators can meet the standard exponential fit well.

\section{Conclusion}

The rental service has been expanding and increasing in terms of proportion of consumption because of the popularity of the Internet, but we still have limit knowledge about the relation of ownership and rental decision. This study combined empirical data, distinguished dimensions of perceived risk (economic, performance, psychological, time and social risk) and studied the relationship between perception and ownership willingness and rental service willingness. 
After demonstration, six hypotheses proposed are supported. The size of ownership perception could reduce willingness to obtain ownership. Hypothesis 1 is the biggest decision variable which influences ownership willingness among all variables. Performance risk is the weakest hypothesis among five dimensions. Psychological risk, time risk and social risk have positive effects on reducing the ownership willingness. At last, reduced ownership willingness increases possibilities of using rental service. It proves that the more risks the customers perceive, the more willingness to own will be reduced. Then customers are more willing to rent than own a product.

\section{Implications and Limitations}

This study is a theoretical development of use-based service consumption (Bardhi and Eckhardt 2012; Belk 2013); through empirical study, we proposed a risk-based model to explain the perception of ownership burden which focus on economic, performance, psychological, time and social risks and provide theoretical support for rental service marketing strategies.

From this study, some managerial recommendation can be acquired. First, in order to encourage rental service selection, the providers should pay attention on comparing the advantages of "ownership burden", that is, reduce five risks customers face: economic risk, performance risk, psychological risk, time risk and social risk. Economic risk is the most important factor that customer concerned. The companies need to provide the service with the price advantage to arouse customer decision. For performance risk, companies need to pay attention to reduce pressure of occupancy and burden of maintenance from purchasing the product. At the same time, the companies need to propose the guarantee on quality and function of service. Service provider can emphasize temporary of service use type and use mature product service to reduce customer psychology risk, time risk and social risk.

This study only researched in car rental industry, some limitations still exist. Researches on many other usage-based services in other fields, such as fashion or tool rent can be done in the future studies. Besides, this study set hypothesis based on previous "Ownership Burden" research, but there could be additional burden by choosing rental service, thus later stage research still needed. Future study may include: research on risk perception related to use-based consumption base on ownership decision; research on risk perception between rent and ownership. In addition, quantitative research on costs and benefits of each mode of consumption can be further expanded in future studies.

\section{References}

Bauer, R. A. (1960). Consumer behavior as risk taking[J]. Dynamic marketing for a changing world, 398.

Berry, L. L., \& Maricle, K. E. (1973). Consumption without ownership: what it means for business[J]. MSU. Business Topics, 21(2), 44-46.

DelVecchio, D, \& Smith, D. C. (2005). Brand-extension price premiums: the effects of perceived fit and extension product category risk[J]. Journal of the Academy of Marketing Science, 33(2), 184-196. https://doi.org/10.1177/0092070304269753

Demsetz, H. (1967). Toward a theory of property rights[J]. The American economic review, 347-359.

Durgee, J. F., \& Colarelli, O. G. (1995). An exploration into renting as consumption behavior[J]. Psychology \& Marketing, 12(2), 89-104. https://doi.org/10.1002/mar.4220120202

Furubotn, E. G., \& Pejovich, S. (1972). Property rights and economic theory: a survey of recent literature[J]. Journal of economic literature, 10(4), 1137-1162.

Galbreth, M. R., Ghosh, B., \& Shor, M. (2012). Social sharing of information goods: Implications for pricing and profits[J]. Marketing Science, 31(4), 603-620. https://doi.org/10.1287/mksc.1120.0706

Kaplan, L. B., Szybillo, G. J., \& Jacoby, J. (1974). Components of perceived risk in product purchase: A cross-validation[J]. Journal of applied Psychology, 59(3), 287. https://doi.org/10.1037/h0036657

Li, Y. J., \& Liao, C. L. (2013). Research on the Relationship between Personal Perception, Innovation Diffusion and Consumer 's Participation in Network Group Purchase [J]. Business Research, 11, 45-53.

Lovelock, C., \& Gummesson, E. (2004). Whither services marketing? In search of a new paradigm and fresh perspectives[J]. Journal of service research, 7(1), 20-41. https://doi.org/10.1177/1094670504266131

Mitchell, V. W. (1999). Consumer perceived risk: conceptualisations and models[J]. European Journal of marketing, 33(1/2), 163-195. https://doi.org/10.1108/03090569910249229

Moeller, S., \& Wittkowski, K. (2010). The burdens of ownership: reasons for preferring renting[J]. Managing 
Service Quality: An International Journal, 20(2), 176-191. https://doi.org/10.1108/09604521011027598

Mumel, D., \& Možina, S. (1999). Vedenje porabnikov[M]. Ekonomsko-poslovna fakulteta.

Schaefers, T., Lawson, S. J., \& Kukar-Kinney, M. (2015). How the burdens of ownership promote consumer usage of access-based services[J]. Marketing Letters, 1-9.

Trocchia, P. J., \& Beatty, S. E. (2003). An empirical examination of automobile lease vs finance motivational processes[J]. Journal of Consumer Marketing, 20(1), 28-43. https://doi.org/10.1108/07363760310456937

Wittkowski, K., Moeller, S., \& Wirtz, J. (2013). Firms' Intentions to Use Nonownership Services[J]. Journal of Service Research, 16(2), 171-185. https://doi.org/10.1177/1094670512471997

$\mathrm{Xu}, \mathrm{H}$. Q. (2012). A Study on the mechanism of risk perception to Consumers' Behavior: An Investigation and Analysis based on car rental consumption. Academic journal of Shangrao normal college, 5, 74-78.

\section{Copyrights}

Copyright for this article is retained by the author(s), with first publication rights granted to the journal.

This is an open-access article distributed under the terms and conditions of the Creative Commons Attribution license (http://creativecommons.org/licenses/by/4.0/). 